\title{
Phytochemical Analysis and Evaluation of Antibacterial Activity of Different Extracts of Soil-Isolated Fungus Chaetomium cupreum
}

\author{
Nazir Ahmad Wani, Waseem Iqbal Khanday', Sharmila Tirumale \\ Department of Microbiology and Biotechnology, Bangalore University, Bengaluru, Karnataka, ${ }^{1} \mathrm{PG}$ and Research Centre in Biotechnology, MGR College, \\ Hosur, Tamil Nadu, India
}

\section{Abstract}

Background: Chaetomium cupreum is soil-isolated pigment-producing fungus used as biocontrol agent. Hypothesis: The aim of the present study was to evaluate the bioactive constituents and antibacterial potential of C. cupreum extracts on bacteria such as Staphylococcus aureus, Bacillus subtilis, Salmonella typhi, and Proteus vulgaris. Materials and Methods: The qualitative and quantitative screening of secondary metabolites was done by standard procedures. The antibacterial activity of different extracts of C. cupreum was determined by agar well diffusion method and broth microdilution methods. Results: Among the different extracts of $C$. cupreum, ethyl acetate and n-butanol extracts exhibited antibacterial activity. In the n-butanol extract, the most susceptible organism was found to be $B$. subtilis with zone of inhibition $18.5 \pm 0.7 \mathrm{~mm}$, followed by P. vulgaris $15.5 \pm 0.7 \mathrm{~mm}$, S. typhi $12.5 \pm 3.5 \mathrm{~mm}$, and $S$. aureus $12.0 \pm 2.8 \mathrm{~mm}$ at $0.5 \mathrm{mg} / \mathrm{ml}$, whereas in the ethyl acetate extract, the most susceptible organism was to found be $P$. vulgaris with zone of inhibition $17.5 \pm 0.7 \mathrm{~mm}$ followed by $B$. subtilis $17.0 \pm 1.4 \mathrm{~mm}$, S. typhi $14.0 \pm 0.7 \mathrm{~mm}$, and $S$. aureus $13.5 \pm 0.7 \mathrm{~mm}$ at $0.5 \mathrm{mg} / \mathrm{ml}$. Conclusion: The obtained results suggest that $C$. cupreum extracts contain compounds that possess antibacterial activity.

Keywords: Azaphilones, bacteremia, bacterial infections, biopigments, Chaetomium cupreum, metabolites, resistance

\section{INTRODUCTION}

Microorganisms have caused epidemic, endemic diseases, and deaths of hundreds of millions of humans as well as animal morbidity and mortality worldwide. Microorganisms have developed sophisticated defense mechanisms for their survival in the host cells and to overcome the host defense system such as cells of the immune system, lysozyme attack, cytokinines, complements, antibodies, and phagocytosis. ${ }^{[1]}$ Bacterial infection process attachment and penetration to epithelial cells, multiplication, synthesis of toxins and enzymes, and finally damages the whole cell. ${ }^{[2]}$ The Staphylococcus aureus is a most pathogenic organism of the genus Staphylococcus, and it causes community-acquired and nosocomial infections worldwide. ${ }^{[3]}$ The $S$. aureus is found in the digestive tracts, livestock, human skin and causes ophthalmic infections with skin infections and sepsis. ${ }^{[4]}$ It is reported that $S$. aureus causes more fatalities in the USA than AIDS because of antibiotic resistance. ${ }^{[5]}$ The skin and soft-tissue infections are caused

\begin{tabular}{|l|l|}
\hline \multicolumn{2}{|c|}{ Access this article online } \\
\hline Quick Response Code: & Website: \\
\hline & www.jnsbm.org \\
\hline & \\
\hline
\end{tabular}

by methicillin-resistant $S$. aureus (MRSA) strain known as USA300 ${ }^{[6]}$ The presence of MRSA has also been established in cats, horses, and rabbits by researchers. ${ }^{[7]}$ Bacillus subtilis damages mammalian membrane by producing lecithinase enzyme. In humans, B. subtilis causes allergic reactions and food poisoning by the production of extracellular toxins. ${ }^{[8]}$ This bacterium causes endocarditis in infants, bacteremia in the patients with the impaired immune system. ${ }^{[9]}$ In hospitals, causes wound infection in hospitalized patients due to the spores production. ${ }^{[9]}$ B. subtilis also contaminates laboratory media. ${ }^{[8]}$

The Salmonella species are Gram-negative bacteria that cause typhoid fever and enterocolitis, intestinal or diarrheal disease

\begin{tabular}{l}
$\begin{array}{l}\text { Address for correspondence: Dr. Sharmila Tirumale, } \\
\text { Department of Microbiology and Biotechnology, Bangalore University, } \\
\text { Bengaluru - 560 056, Karnataka, India. } \\
\text { E-mail: sharmilabub@gmail.com }\end{array}$ \\
$\begin{array}{l}\text { Submitted: 27-May-2019 } \\
\text { Accepted: } 20-J u l-2019\end{array}$ \\
\hline
\end{tabular}

This is an open access journal, and articles are distributed under the terms of the Creative Commons Attribution-NonCommercial-ShareAlike 4.0 License, which allows others to remix, tweak, and build upon the work non-commercially, as long as appropriate credit is given and the new creations are licensed under the identical terms.

For reprints contact: reprints@medknow.com

How to cite this article: Wani NA, Khanday WI, Tirumale S. Phytochemical analysis and evaluation of antibacterial activity of different extracts of soil-isolated fungus Chaetomium cupreum. J Nat Sc Biol Med 2020;11:72-80. 
Wani, et al:: Phytochemical analysis and evaluation of antibacterial activity of Chaetomium cupreum

in different hosts. ${ }^{[10]}$ Typhoid fever is one of the global health problem caused by the Salmonella enterica serovar typhi. ${ }^{[1]}$ Typhoid fever transmitted by the ingestion of food, water, or animal products or close contact with an infected individual contaminated with $S$. enterica serovar typhi bacteria. ${ }^{[12]}$ The Salmonella bacteria infect different cells of the immune system and epithelial cells by surviving within the membrane-bound compartment Salmonella-containing vacuole for its virulence. ${ }^{[13]}$ The genus Proteus of Enterobacteriaceae family ${ }^{[14]}$ is a Gram-negative, rod-shaped bacteria, cause urinary tract infection (UTI) and wound infections humans and animals. The Proteus bacilli cause UTIs, and colonize in different organs of host such as the urethra, ureter bladder, and kidneys. ${ }^{[15]}$ Proteus transmitted by contaminated meat or food items is described as an opportunistic etiological agent of respiratory tract and wounds infections, eyes, ears, nose, burns, skin throat, and gastroenteritis. ${ }^{[16]}$ The increasing drug toxicity and multidrug resistant to bacteria are serious problems to the well-being of humankind worldwide.

Biopigments or microbial pigments are natural-colored substances produced by microorganisms, especially fungi and bacteria. Biopigments are produced from natural sources which can replace synthetic dyes. ${ }^{[17]}$ Microorganisms are produced variety of pigments by fermentation process which has higher pigment yields and lower residues compared to that of the plants and animals. ${ }^{[18]}$ Natural pigments are one of the research alternatives with potent inhibitory properties and minimal side effects. Fungi are also known to produce various pigments with different structures and biological activities. The Chaetomium species produce a class of secondary metabolites called azaphilones. Azaphilones are fungal pigments with pyrone-quinone structures and a highly oxygenated bicyclical core with a chiral quaternary center. ${ }^{[19]}$ Azaphilones possess antimicrobial, anticancer, antiviral, antioxidant, antifungal, and anti-inflammatory activities by the production of vinylogous gamma-pyridones. ${ }^{[20]}$ The purpose of the present study was to extract the secondary metabolites/biopigments from fungus Chaetomium cupreum and explore the antimicrobial activity.

\section{Materials and Methods}

\section{Isolation of Chaetomium cupreum}

The C. cupreum was isolated from a litter soil sample collected from the GKVK Campus, Bengaluru, Karnataka, India. The isolation of fungus $C$. cupreum was carried out from litter soil sample collected from the GKVK campus, Bengaluru, Karnataka, India. The isolation was carried out by the serial dilution method on potato dextrose agar (PDA) medium. A volume of $50 \mathrm{mg}$ of soil sample was dissolved in $10 \mathrm{ml}$ of distilled water in a test tube. Then, $1 \mathrm{ml}$ of soil sample was spread onto the PDA medium and incubated at room temperature. After incubation growth of number of different fungal colonies were observed, from which pigment-producing colony was transferred to a new PDA medium plates and incubated at room temperature at $28^{\circ} \mathrm{C}$ for $3-4$ days.

\section{Identification Chaetomium cupreum}

The pure fungus culture was identified based on morphological and microscopic characteristics and named as C. cupreum-SS02. ${ }^{[21]}$ The morphological identity of C. cupreum was confirmed by National Fungal Culture Collection of India (NFCCI), by Agharkar Research Institute, Pune, Maharashtra, India. The molecular technique based on the molecular phylogenetics of the internal transcribed spacer (ITS) region gene sequencing, using universal primers, ITS-1 (TCCGTAGGTGAACCTGCGG) was the forward primer and ITS-4 TCCTCCGCTTATTGATATGC) was the reverse primer was performed. ${ }^{[22]}$ In GeneBank, homologous sequences search was performed using Basic Local Alignment Search Tool (BLAST) (National Center for Biotechnology Information; http://www.ncbi.nlm.nih.gov/blast). ${ }^{[23]}$ The BLAST search for ITS sequence analysis available in GenBank showed 99\% homology with other strains of C. cupreum. The sequence was deposited in National Centre for Biotechnology information (NCBI) GenBank with accession number KF668034. The culture was deposited in the NFCCI, with accession number NFCCI 3117. The isolated fungus was maintained on PDA plates and PDA slants at $4^{\circ} \mathrm{C}$.

\section{Submerged fermentation}

For inoculum preparation, the fungus was grown at $25^{\circ} \mathrm{C}$ on a PDA plate for 7 days, then 5-mm mycelial discs were bored out from the periphery of the colony and transferred to $250 \mathrm{ml}$ Erlenmeyer flasks containing $100 \mathrm{ml}$ of potato dextrose broth (PDB) and incubated at $26^{\circ} \mathrm{C} \pm 2{ }^{\circ} \mathrm{C}$ on a rotary shaker at $120 \mathrm{rpm}$ for 20 days to achieve the highest pigment production. ${ }^{[24]}$ Submerged fermentation produces high mycelial production and thus high is the pigment production in shorter time. ${ }^{[25]}$ The culture of edible mushrooms produces high pigment production through submerged fermentation. ${ }^{[24]}$ The $C$. cupreum showed the maximum pigment production in PDB medium. The PDB medium contains nutrients such as metal ions and other micronutrients useful for the enzymes to work effectively and increase the metabolite and pigment production. ${ }^{[26]}$

\section{Extraction of extracellular pigments/metabolites}

The extraction of pigments was carried out according to the method. ${ }^{[27]}$ After 20 days of incubation, biomass was removed by filtration through Whatman No. 1 filter paper and the broth containing the extracellular pigment/metabolites was obtained. The cultural broth obtained was used for extraction of pigments/compounds by the liquid-liquid method in $500 \mathrm{ml}$ of separating funnel using four different solvents from nonpolar to polar (chloroform, ethyl acetate, n-butanol, and methanol) in the ratio of $1: 1$. The $50 \mathrm{ml}$ of filtered broth and $50 \mathrm{ml}$ of solvent was taken in separating funnel and shaken well for $20 \mathrm{~min}$ and allowed to stand until the aqueous layer, and organic layers get separated. The organic layer was collected, filtered through Whatman No. 1 filter paper, and transferred to $250 \mathrm{ml}$ of beaker. This process was repeated three times with the same broth and same solvent until no more pigment diffused into the solvent. 
The whole broth was extracted by using similar procedure with chloroform, ethyl acetate, n-butanol, and methanol. Then, the organic layer was evaporated using vacuum rotary evaporator at $45^{\circ} \mathrm{C}$. The crude dried extract was obtained and stored at $4^{\circ} \mathrm{C}$ for future use.

\section{Estimation of pigment yield}

The mycelium after 20 days of incubation at $28^{\circ} \mathrm{C} \pm 2^{\circ} \mathrm{C}$ at room temperature was separated from broth by filtration through Whatman No. 1 filter paper. The separated mycelium was washed thrice with distilled water and then air-dried at room temperature. The dry weight (DW) of the mycelium and the crude extract produced was estimated. The pigment yield was expressed as $\mathrm{mg} / \mathrm{g}$ mycelial DW in $1 \mathrm{~L}^{\text {of }} \mathrm{PDB}^{[28]}$ and calculated by the formula:

Biomass estimation $=(\mathrm{DW}$ of crude extract $/ \mathrm{DW}$ of mycelium $)$ $\times 1000$

\section{Qualitative screening of secondary metabolites}

The isolated four different solvent extracts of C. cupreum were screened for the presence of different secondary metabolites by standard procedure. ${ }^{[29,30]}$ The stock solution of $1.0 \mathrm{mg}$ of fungal extract was diluted in $1.0 \mathrm{ml}$ of the respective solvent.

\section{Alkaloids}

Dragendroff's test - A volume of $0.5 \mathrm{ml}$ of fungal extract was mixed with $2 \mathrm{ml}$ of hydrochloric acid $(\mathrm{HCl})$ and $1.0 \mathrm{ml}$ of Dragendroff's reagent. The formation of orange-red precipitate confirms the presence of alkaloids.

Mayor's test - A volume of $1.2 \mathrm{ml}$ of the fungal extract was taken in a test tube, $0.2 \mathrm{ml}$ of $1 \%$ aqueous $\mathrm{HCl}$ was added and kept in water bath and $0.1 \mathrm{ml}$ Mayer's reagent (potassium mercuric iodide) were added. The appearance of yellow-colored precipitate indicates alkaloids.

\section{Flavonoids}

Alkaline reagent test - To a volume of $1.0 \mathrm{ml}$ of the fungal extract, few drops of diluted sodium hydroxide $(\mathrm{NaOH})$ were added. The appearance of yellow color formation which later becomes colorless on addition of a few drops of diluted acid and thus confirms the presence of flavonoids.

Shinoda test - To a volume of $4 \mathrm{ml}$ of fungal extract, $1.5 \mathrm{ml}$ methanol solution (50\%) was added, then heated, and metal magnesium was added. Then, few drops of $\mathrm{HCl}$ were added, red color will be observed for flavonoids and orange color for flavones.

\section{Carbohydrates}

Molisch's test - A small quantity of the fungal extract was dissolved separately in $4 \mathrm{ml}$ of distilled water and filtered, then few drops of alcoholic $\alpha$-naphthol solution (1\%) and $2 \mathrm{ml}$ of conc. sulfuric acid was added. The appearance of brown ring at the junction of two liquids indicates the presence of carbohydrates.

\section{Glycosides}

Legal's test - A volume of fungal extract was hydrolyzed in
$\mathrm{HCl}$ solution in a water bath. Then, $1.0 \mathrm{ml}$ of pyridine and few drops of sodium nitroprusside solution were added and few drops of $\mathrm{NaOH}$ were added. The appearance of pink-red color confirms the presence of glycosides.

\section{Saponins}

Foam test - To $1 \mathrm{ml}$ fungal extract, $2 \mathrm{ml}$ of distilled water was added and shaken well. The persistent foam formation indicates the presence of saponins.

Lead acetate test - A volume of $1 \mathrm{ml}$ of the fungal extract was treated with $1 \%$ lead acetate solution. The appearance of white precipitate confirms the presence of saponins.

\section{Tannins}

Ferric chloride test - To a volume of $0.5 \mathrm{ml}$ of fungal extract, $1.0 \mathrm{ml}$ of water was added in a test tube and filtered. Then, few drops of $0.1 \%$ ferric chloride were added and observed for brownish-green or blue-black coloration.

Lead acetate test - To a volume of $5.0 \mathrm{ml}$ of the fungal extract, a few drops of $1 \%$ lead acetate was added. The formation of yellow precipitate confirms the presence of tannins.

Potassium dichromate test - A $5.0 \mathrm{ml}$ of the fungal extract was mixed with $1.0 \mathrm{ml}$ aqueous potassium dichromate solution (10\%). The yellowish-brown precipitate confirms the presence of tannins.

\section{Phytosterol}

Salkowski test - A volume of $1.0 \mathrm{ml}$ of fungal extract was mixed with $1.0 \mathrm{ml}$ of conc. sulfuric acid. The appearance of red color confirms the presence of sterols.

\section{Phenolic}

Folin-Ciocaltaeu test - To a volume of $1.0 \mathrm{ml}$ of fungal extract, $1.0 \mathrm{ml}$ of diluted Folin-Ciocaltaeu reagent (1:1) was added. The appearance of blue color confirms the presence of phenolic compounds.

\section{Terpenoids}

Salkowki's test - To a volume of $2.0 \mathrm{ml}$ of fungal extract, a few drops of concentrated sulfuric acid were added. The formation of reddish-brown precipitate produced indicates the presence of terpenoids.

\section{Coumarins}

To a volume of $2 \mathrm{ml}$ of fungal extract, $3 \mathrm{ml}$ of $10 \% \mathrm{NaOH}$ was added. The formation of yellow color indicates the presence of coumarins.

\section{Azaphilones}

To a volume of $2 \mathrm{ml}$ of fungal extract was mixed with few drops of ammonia. The formation of red for purple color indicates the presence of azaphilones.

\section{Quantitative estimation of secondary metabolites}

Determination of total flavonoid content

The flavonoids content was determined spectrophotometrically according to the aluminum chloride $\left(\mathrm{AlCl}_{3}\right)$ method. ${ }^{[31]}$ Flavonoids give yellow color when treated with $\mathrm{AlCl}_{3}$ reagent $(1 \% \mathrm{w} / \mathrm{v})$, 
and this principle is used in flavonoid estimation. Fungal extract $0.5 \mathrm{ml}$ was mixed with $0.15 \mathrm{ml}$ of sodium nitrite $(5 \%)$ and $2 \mathrm{ml}$ distilled water and the reaction mixture was allowed to react for $6 \mathrm{~min}$. After $6 \mathrm{~min}, 0.15 \mathrm{ml} \mathrm{AlCl} 3\left(10 \% \mathrm{AlCl}_{3} \mathrm{w} / \mathrm{v}\right)$ solution and $2 \mathrm{ml}$ of $\mathrm{NaOH}(4 \%)$ solution are added, then $5 \mathrm{ml}$ distilled water was added. The solution was allowed to react for $15 \mathrm{~min}$ and absorbance was measured at $510 \mathrm{~nm}$. The calibration curve was generated from rutin reference standard and results of total flavonoid content (TFC) are expressed as rutin equivalents (REs/g DW).

\section{Antibacterial activity of solvent extracts from Chaetomium cupreum}

\section{Bacterial strains}

The cultures used for antibacterial activity such as $S$. aureus (NCIM 2079), Salmonella typhi (NCIM 2051), Proteus vulgaris (2027), and B. subtilis (2063) were obtained from the National Chemical Laboratory, Pune, Maharashtra, India. All the tested bacteria were maintained on the Mueller Hinton agar (MHA) medium.

\section{Agar well diffusion method}

The well diffusion method was employed for the determination of antimicrobial activity ${ }^{[32]}$ with slight modifications. Briefly, $5 \mathrm{~mm}$ wells were made on preinoculated solidified agar medium (inoculum size: $100 \mu \mathrm{l}$ of a microbial suspension containing $10^{8} \mathrm{CFU} / \mathrm{ml}$ of bacteria, (McFarland's standard), wells were filled with $50 \mu \mathrm{l}$ of n-butanol and ethyl acetate extracts dissolved in dimethyl sulfoxide (DMSO) $(0.5$ to $2 \mathrm{mg} / \mathrm{ml})$ and the plates were incubated at $37^{\circ} \mathrm{C}$ for $24 \mathrm{~h}$. DMSO was used as negative control $(50 \mu \mathrm{l} / \mathrm{ml})$ and streptomycin $(25 \mu \mathrm{g} / \mathrm{ml})$ as positive control. The zone of Inhibition diameters was measured in millimeters $(\mathrm{mm})$ after the incubation period.

Determination of minimum inhibitory concentration and minimum bactericidal concentration by Broth microdilution method

The broth microdilution method was used (M27-A2, Clinic and Laboratory Standards Institute (CLSI) $)^{[33]}$ to determine the minimum inhibitory concentrations (MICs) and minimum bactericidal concentrations (MBCs). Two hundred microliters of two-fold serially diluted n-butanol and ethyl acetate extracts in nutrient broth $(1000 \mathrm{TO} 0.95 \mu \mathrm{g} / \mathrm{ml})$ were added to the wells of 96-well microtiter plate and inoculated with $50 \mu \mathrm{l}$ of a bacterial suspension containing $10^{8} \mathrm{CFU} / \mathrm{ml}$ and incubated at $37^{\circ} \mathrm{C}$ for $24 \mathrm{~h}$. The antibiotic streptomycin was used as positive control and DMSO as a negative control. After incubation, the MICs and MBCs values were recorded. Fifty microliters of cultured broth was radically streaked onto the MHA medium and further incubated for respective time and temperature as mentioned above.

\section{RESULTS}

\section{Isolation and identification of the fungus}

Species of Chaetomium are capable of producing novel secondary metabolites. In the present study, C. cupreum is taken for testing its production for secondary metabolites. The isolated fungus was identified as C. cupreum based on morphological and microscopic characteristics. The identification was further confirmed by NFCCI and Fungal Identification Service, Agharkar Research Institute, Pune, Maharashtra, India. The culture was deposited in the NFCCI, with accession number NFCCI 3117. BLAST search performed for the sequence of ITS analysis showed $99 \%$ homology with other strains of C. cupreum available in GenBank. The sequence was deposited in NCBI GenBank with accession number KF668034.

\section{Cultural Morphology.}

The C. cupreum exhibited typical white cottony colonies on the PDA. The diffusion of deep red color into the media was observed around the colony after 7-10 days of incubation on PDA plate, which suggested that $C$. cupreum produces extracellular, water-soluble pigments [Figure 1].

\section{Extraction of secondary metabolites}

The extraction of extracellular metabolites from C. cupreum was done by using cold extraction method [Figure 2]. The extraction revealed high pigment yield through submerged fermentation method from C. cupreum. The extraction was done by using four different solvents from nonpolar to polar in the consecutive manner (chloroform, ethyl acetate, n-butanol, and methanol).

\section{Estimation of pigment yield}

The dry yield of extracellular product produced by C. cupreum after submerged fermentation was estimated. The dry pigment yield for chloroform extract was $26.85 \mathrm{mg} / \mathrm{g} \mathrm{DW}$, ethyl acetate extract $120.06 \mathrm{mg} / \mathrm{g}$ DW, n-butanol extract $69.85 \mathrm{mg} / \mathrm{g} \mathrm{DW}$, and methanol extract $176.73 \mathrm{mg} / \mathrm{g}$ DW from $1 \mathrm{~L}$ of PDB after 20 days of incubation [Figure 3]. The maximum pigment yield was found in methanol extract, followed by ethyl acetate extract and n-butanol extract, whereas least yield was found in chloroform extract. The chloroform extract was yellow
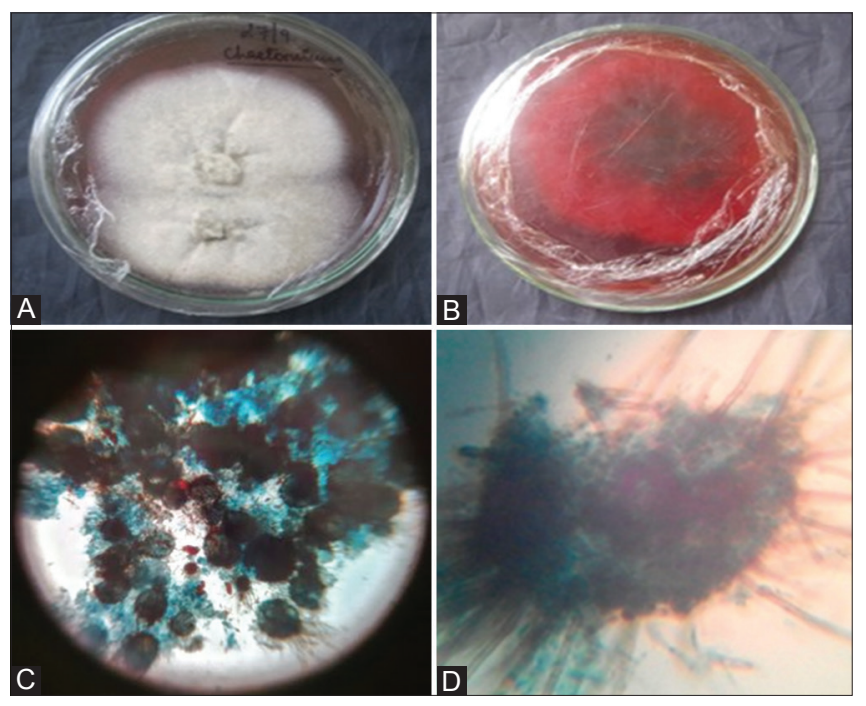

Figure 1: Morphology of Chaetomium cupreum on potato dextrose agar medium. A-dorsal view, B-ventral view, C-Perithecia, D-Perithecia with ascospores by using lactophenol cotton blue stain 
Wani, et al.: Phytochemical analysis and evaluation of antibacterial activity of Chaetomium cupreum

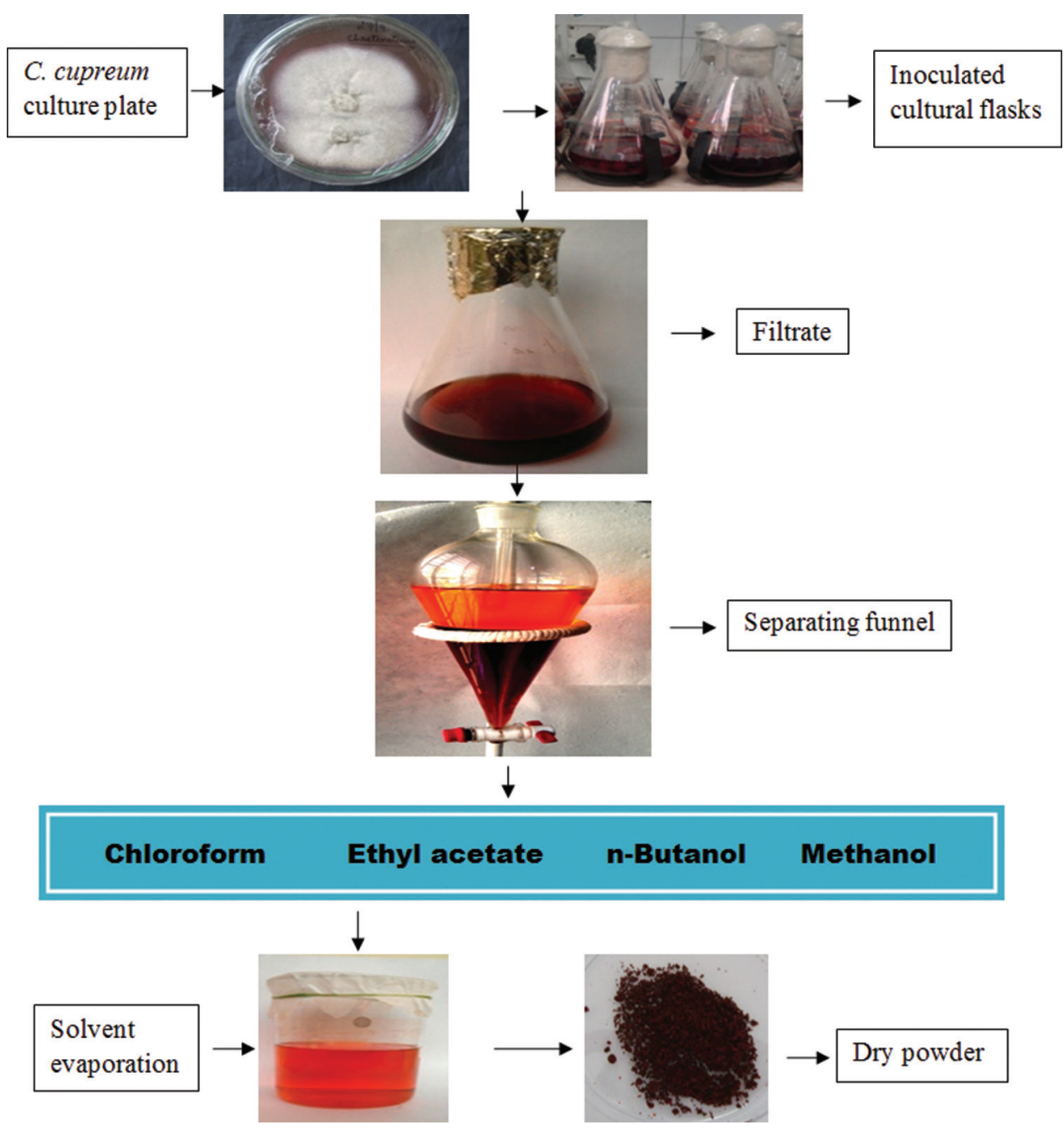

Figure 2: Extraction of pigments from Chaetomium cupreum by different solvents

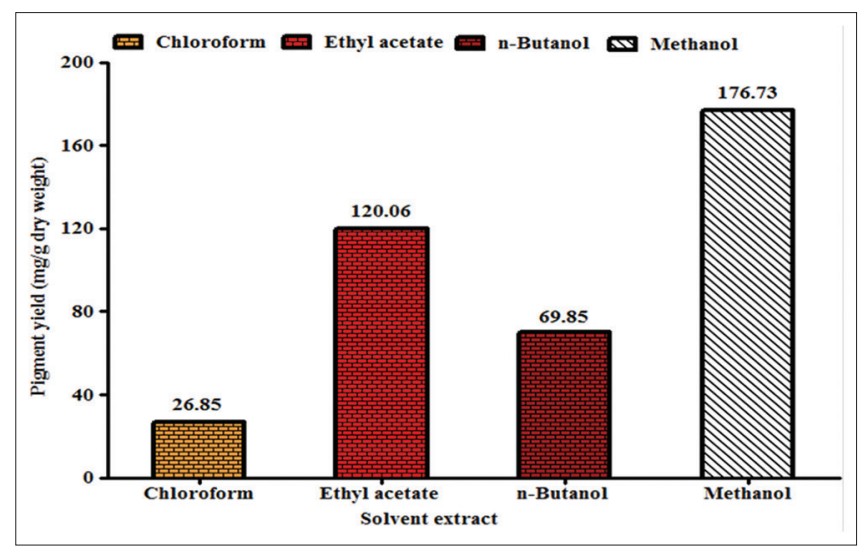

Figure 3: Estimation of pigment yield of different solvent extracts of Chaetomium cupreum

in color, whereas ethyl acetate was bright red and n-butanol was sticky paste deep red in color and methanol extract was colorless paste [Figure 4].

\section{Qualitative screening of secondary metabolites}

The fermentation and extraction method showed different types of secondary metabolites in C. cupreum extracts. The secondary metabolites such as flavonoids, carbohydrates, saponins, tannins, glycosides, phytosterol, phenolic terpenoids, azaphilones, and coumarins compounds were present, whereas alkaloids were absent in the C. cupreum extracts [Table 1]. In chloroform extract of $C$. cupreum different types of secondary metabolites such as, flavonoids, saponins, tannins, terpenoid, azaphilones, and coumarins were present, whereas carbohydrates and phenolic compounds were absent. In ethyl acetate extract, except alkaloids and terpenoid all other secondary metabolites such as flavonoids, carbohydrates, saponins, tannins, glycosides, phytosterol, phenolic, azaphilones, and coumarins were present. In n-butanol extract, secondary metabolites such as flavonoids, saponins, tannins, azaphilones, and coumarins compounds were present, whereas carbohydrates, alkaloids, and phenolic compounds were absent. In methanol extract, all secondary metabolites were present except alkaloids and phytosterol compounds. Thus, these results showed that the extraction method is greatly based on the solvent polarity. Terpenoids also possess antimicrobial, antifungal, antiviral, 
anti-allergenic, antispasmodic, antihyperglycemic, and immunomodulatory properties. Saponins have precipitating and coagulating properties for red blood cells. The C. cupreum extracts also contain carbohydrates, glycosides, and coumarins which are known to be useful for the immune system by increasing body strength. The present study indicated that $C$. cupreum extracts are potential source of different secondary metabolites such as flavonoids, saponins, tannins, phytosterol, phenolic, azaphilones, coumarins, and terpenoid compounds. All the extracts contain flavonoids, terpenoids, and saponins.

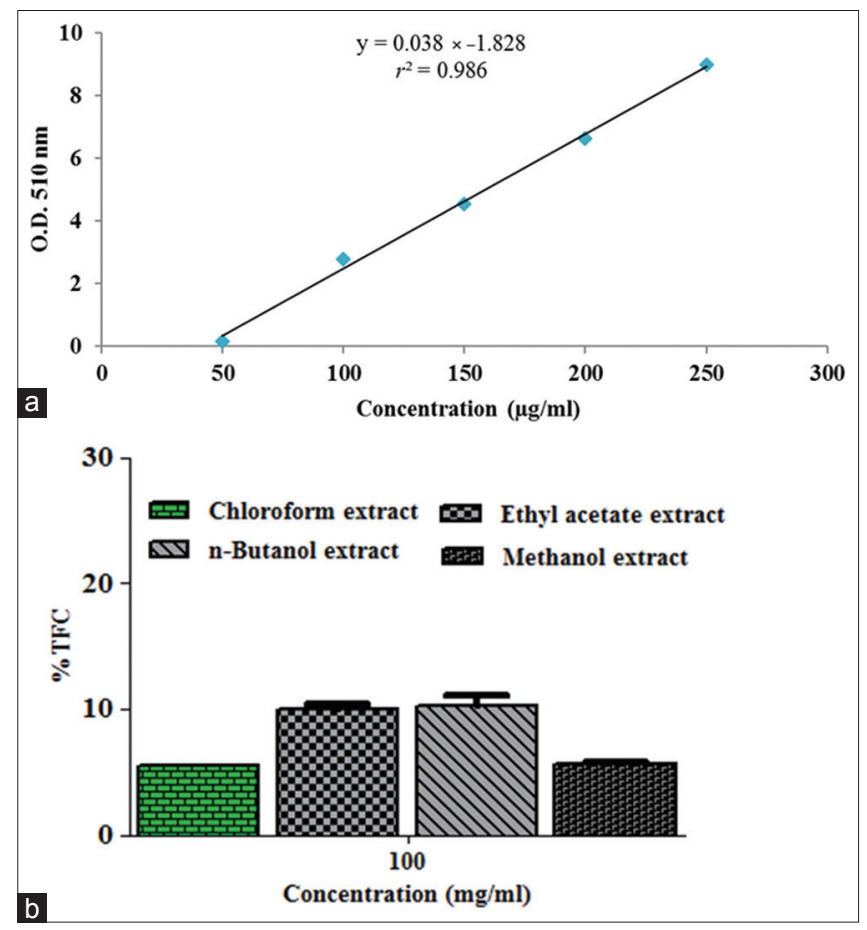

Figure 4: (a) Rutin standard calibration curve. (b) Determination of total flavonoid content by aluminum chloride method. Experimental results are expressed as mean \pm standard deviation $(n=3)$

\section{Quantitative estimation of secondary metabolites Total flavonoid content}

The TFC of C. cupreum was obtained from calibration curve of standard rutin $\left(\mathrm{y}=0.38 \times 1.828 ; r^{2}=0.986\right)$ and expressed as milligrams RE/100 g DW of the extract [Figure 5a]. The TFC of different extract of C. cupreum is presented in Figure $5 \mathrm{~b}$. The results showed significant amount of flavonoid content present in all the four extracts of C. cupreum. In chloroform extract, the TFC was obtained with a value of $5.52 \pm 0.00 \mathrm{mg}$ of Rutin equivalent/grams dry weight, in ethyl acetate extract the flavonoid content with the value of $9.98 \pm 2.87 \mathrm{mg} \mathrm{RE} / \mathrm{g}$ DW, in n-butanol extract the flavonoid content with the value of $10.23 \pm 2.87 \mathrm{mg} \mathrm{RE} / \mathrm{g} \mathrm{DW}$, and in methanol extract the flavonoid content with the value of $5.61 \pm 0.19 \mathrm{mg}$ RE/g DW was obtained at $50 \mu \mathrm{g} / \mathrm{ml}$ concentration. The results showed that n-butanol extract possesses higher flavonoid content than the ethyl acetate extract of $C$. cupreum at different concentrations.

The results obtained showed higher TFC in n-butanol extract $(10.23 \%)$ followed by ethyl acetate extract $(9.98 \%)$, methanol extract (5.61\%), and chloroform extract (5.52\%). The flavonoid content percentage increased with increase in concentration. This indicates that middle polar solvents are more suitable for flavonoid compound extraction than the polar solvents. The TFC of methanolic extracts of two endophytic fungi Aspergillus species (CPIL-1) and Penicillium species (CPIMR-2) in terms of quercetin equivalent, the flavonoid content was $130.50 \pm 6.11 \mathrm{mg} / \mathrm{g}$ and $94.91 \pm 4.48 \mathrm{mg} / \mathrm{g} \mathrm{DW}$, respectively, of fungal extract. ${ }^{[34]}$ Thus, from the present investigation, medicinal properties of the C. cupreum can be identified based on the phytochemicals present in it.

\section{Antibacterial activity \\ Antibacterial activity of ethyl acetate extract}

The effect of ethyl acetate extract of $C$. cupreum on the antibacterial activity is presented in Figure $5 \mathrm{a}$ and $\mathrm{b}$. In

\begin{tabular}{|c|c|c|c|c|c|}
\hline Secondary metabolites & Tests & $\begin{array}{c}\text { Chloroform } \\
\text { extract }\end{array}$ & $\begin{array}{c}\text { Ethyl acetate } \\
\text { extract }\end{array}$ & $\begin{array}{c}\text { n-butanol } \\
\text { extract }\end{array}$ & $\begin{array}{c}\text { Methanol } \\
\text { extract }\end{array}$ \\
\hline \multirow[t]{2}{*}{ Alkaloids } & Dragendroffs & - & - & - & - \\
\hline & Mayers & - & - & - & - \\
\hline Test for flavonoids & Alkaline reagent & + & + & + & + \\
\hline Test for carbohydrates & Molischs & - & + & - & + \\
\hline Test for glycosides & Legals & - & + & + & + \\
\hline \multirow[t]{2}{*}{ Test for saponins } & Foam & + & + & + & + \\
\hline & Lead acetate & + & + & + & + \\
\hline \multirow[t]{3}{*}{ Test for tannins } & Ferric chloride & - & + & + & + \\
\hline & Lead acetate & + & + & + & + \\
\hline & Potassium dichromate & + & + & + & + \\
\hline Test for phytosterol & Salkowski & - & + & - & - \\
\hline Test for phenolic compounds & Follin ciocalteau & - & + & - & + \\
\hline Test for terpenoids & Salkowki & + & - & + & + \\
\hline Coumarins & $\mathrm{NaOH}$ & + & + & + & + \\
\hline Azaphilones & Ammonia & + & + & + & + \\
\hline
\end{tabular}




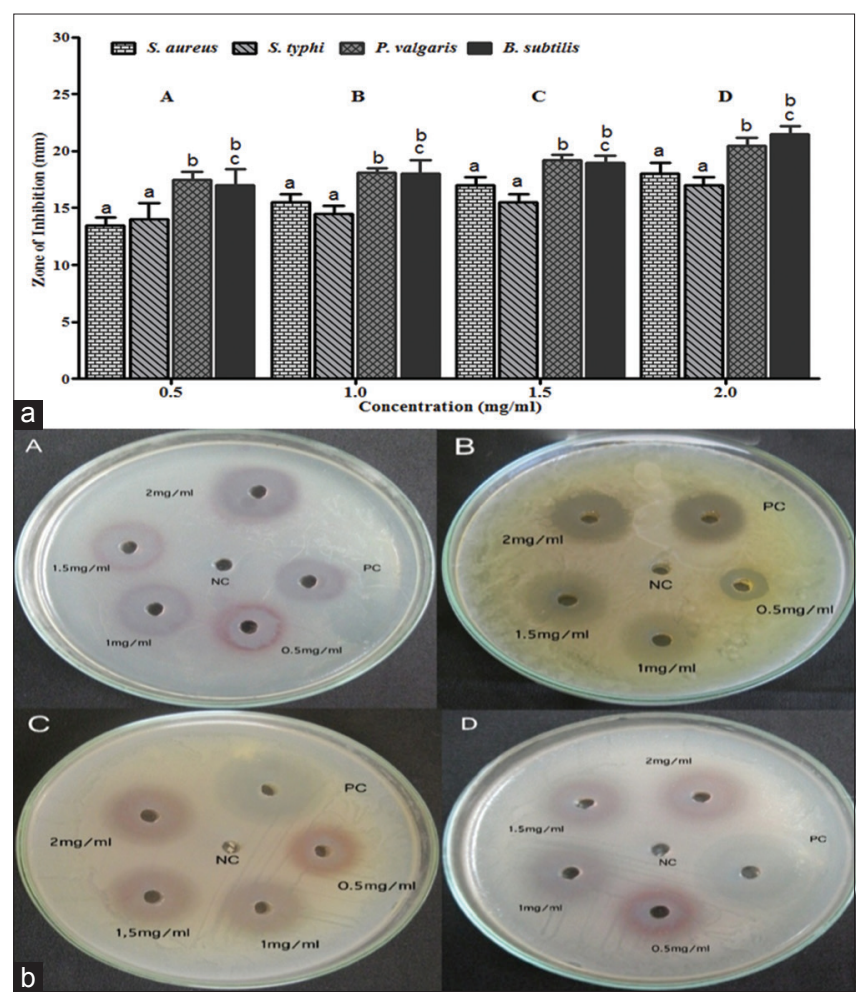

Figure 5: (a) Antibacterial activity of ethyl acetate extract of Chaetomium cupreum by agar well diffusion method. Values are represented as mean \pm standard deviation $(n=3)$. Significance difference between the extracts is represented in lower case and between the concentrations in upper case. Those not sharing the same letter are significantly different at $P<0.05$. (b) The zone of inhibition diameter at different concentration of the ethyl acetate extract of the Chaetomium cupreum. The zone of inhibition was measured against (A) Staphylococcus aureus, (B) Salmonella typhi, (C) Proteus vulgaris, (D) Bacillus subtilis. (Positive control (PC) - Tetracycline, Negative control (NC) - DMSO)

ethyl acetate extract of $C$. cupreum, the most susceptible organism was found to be $P$. vulgaris with zone of inhibition of $17.50 \pm 0.70 \mathrm{~mm}$ in diameter followed by B. subtilis $17.00 \pm 1.40 \mathrm{~mm}, S$. typhi $14.00 \pm 140 \mathrm{~mm}$, and $S$. aureus $13.50 \pm 0.70 \mathrm{~mm}$ at $0.5 \mathrm{mg} / \mathrm{ml}$, whereas at higher concentration, the zone of inhibition of $B$. subtilis was $21.50 \pm 0.70 \mathrm{~mm}$ in diameter, followed by $P$. vulgaris $20.50 \pm 0.70, S$. aureus $18.00 \pm 0.95 \mathrm{~mm}$, and $S$. typhi $17.00 \pm 0.70 \mathrm{~mm}$ at $2.0 \mathrm{mg} / \mathrm{ml}$.

\section{Antibacterial activity of $n$-butanol extract}

The effect of antibacterial activity of n-butanol extract of C. cupreum is presented in Figure 6a and b. In n-butanol extract of $C$. cupreum, the most susceptible bacteria was found to be $B$. subtilis with zone of inhibition of $18.50 \pm 0.70 \mathrm{~mm}$ in diameter, followed by $P$. vulgaris $15.50 \pm 0.70 \mathrm{~mm}$ and $S$. typhi $12.15 \pm 0.90 \mathrm{~mm}$, whereas $S$. aureus was the least sensitive with zone of inhibition of $12.00 \pm 2.98 \mathrm{~mm}$ in diameter at $0.5 \mathrm{mg} / \mathrm{ml}$. Similarly, at higher concentration of n-butanol extract, $B$. subtilis was most sensitive with zone of inhibition of $21.50 \pm 0.93 \mathrm{~mm}$ in diameter followed by P. vulgaris $20.00 \pm 0.90 \mathrm{~mm}$ and $S$. typhi $17.50 \pm 0.85 \mathrm{~mm}$, whereas $S$. aureus was with zone of inhibition $15.00 \pm 0.40 \mathrm{~mm}$

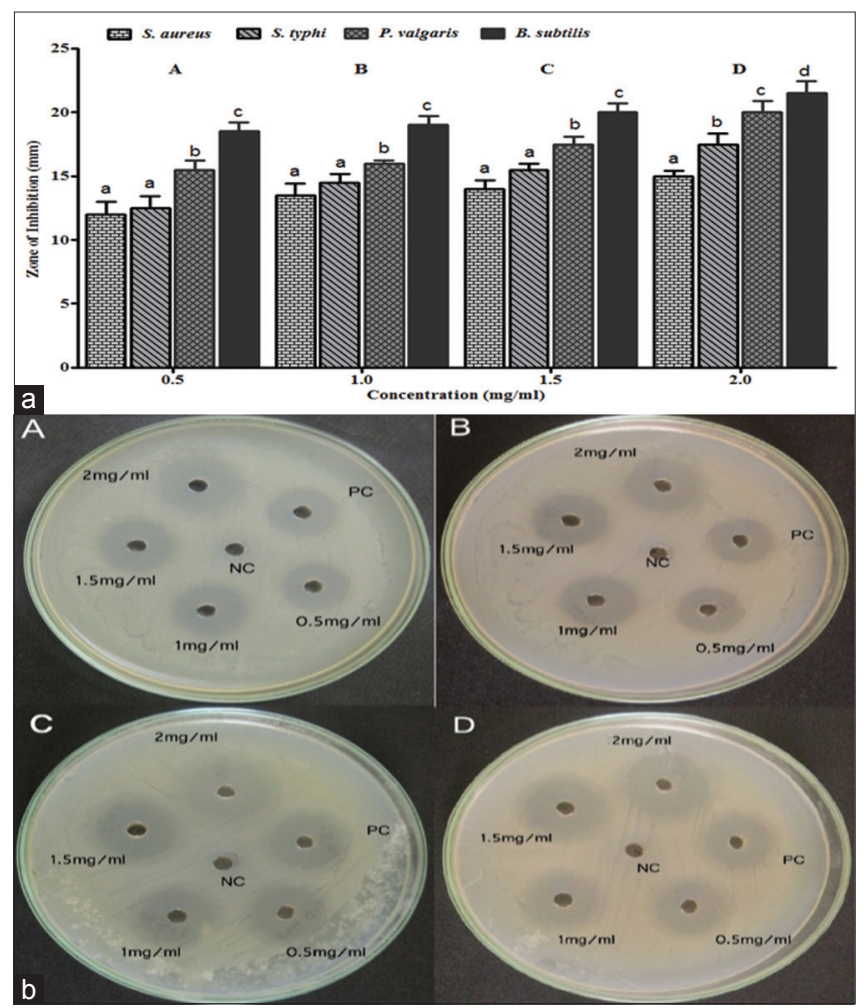

Figure 6: (a) Antibacterial activity of n-butanol extract of Chaetomium cupreum by agar well diffusion method. Values are represented as mean \pm standard deviation $(n=3)$. Significance difference between the extracts is represented in lower case and between the concentrations in upper case. Those not sharing the same letter are significantly different at $P<0.05$. (b) The zone of inhibition diameter at different concentration of the n-butanol extract of the $C$. cupreum. The zone of inhibition were measured against (A) Staphylococcus aureus, (B) Salmonella typhi, (C) Proteus vulgaris, (D) Bacillus subtilis. (Positive control (PC) - Tetracycline, Negative control (NC) - DMSO

in diameter at $2.0 \mathrm{mg} / \mathrm{ml}$. In the butanol extract, it was observed that all the four bacteria exhibited antibacterial activity with maximum zone of inhibition ranging from $12.00 \pm 0.98$ to $18.50 \pm 0.70 \mathrm{~mm}$ in diameter at $0.5 \mathrm{mg} / \mathrm{ml}$ and $15.00 \pm 0.40-21.50 \pm 0.93 \mathrm{~mm}$ in diameter at $2.0 \mathrm{mg} / \mathrm{ml}$. The comparison of the standard compound with C. cupreum extracts in antimicrobial activity is represented in Table 2.

\section{Minimum inhibitory concentrations}

The MIC values of n-butanol and ethyl acetate extract of $C$. cupreum are presented in Table 3. The MICs values of n-butanol extract of C. cupreum exhibited by each organism is $0.62 \mathrm{mg} /$ $\mathrm{ml}$ against both $S$. aureus and $P$. vulgaris, $0.31 \mathrm{mg} / \mathrm{ml}$ against B. subtilis and $0.25 \mathrm{mg} / \mathrm{ml}$ against $S$. typhi, respectively. Whereas, the MIC values of ethyl acetate extract exhibited by different organisms are $0.015 \mathrm{mg} / \mathrm{ml}$ against $S$. typhi, $0.031 \mathrm{mg} / \mathrm{ml}$ against $P$. vulgaris, $0.062 \mathrm{mg} / \mathrm{ml}$ against $S$. aureus, and $0.125 \mathrm{mg} / \mathrm{ml}$ against $B$. subtilis. The MIC values of standard compound observed are $0.031 \mu \mathrm{g} / \mathrm{ml}$ for $P$. vulgaris and $S$. aureus, $0.062 \mu \mathrm{g} / \mathrm{ml}$ for B. subtilis, and $0.125 \mu \mathrm{g} / \mathrm{ml}$ for S. typhi. The antimicrobial activity of dichloromethane of Chaetomium atrobrunneum with zone of inhibition $25 \mathrm{~mm}$ against 
Wani, et al:: Phytochemical analysis and evaluation of antibacterial activity of Chaetomium cupreum

\begin{tabular}{lcccc}
\hline \multicolumn{5}{l}{ Table 2: The comparison of standard compound tetracycline with C. cupreum extracts in antimicrobial activity } \\
\hline & Antibacterial activity \\
\hline & Proteus vulgaris & Bacillus subtilis & Salmonella typhi & Staphylococcus aureus \\
\hline Ethyl acetate extract $(0.5 \mathrm{mg} / \mathrm{ml})$ & $17.50 \pm 0.70$ & $17.00 \pm 1.40$ & $14.00 \pm 140$ & $13.50 \pm 0.70$ \\
$\mathrm{n}$-Butanol extract $(0.5 \mathrm{mg} / \mathrm{ml})$ & $15.50 \pm 0.70$ & $18.50 \pm 0.70$ & $12.15 \pm 0.90$ & $12.00 \pm 2.98$ \\
Tetracycline $(25 \mu \mathrm{l} / \mathrm{ml})$ & $24.00 \pm 0.70$ & $23.50 \pm 0.70$ & $18.00 \pm 0.87$ & $16.00 \pm 0.90$ \\
\hline
\end{tabular}

Table 3: MIC and MBC of n-butanol and ethyl acetate extracts of $C$. cupreum

\begin{tabular}{lccccccc}
\hline Name of organism & \multicolumn{1}{c}{ n-Butanol } & \multicolumn{3}{c}{ Ethyl acetate } & \multicolumn{3}{c}{ Tetracycline } \\
\cline { 2 - 7 } & \multicolumn{5}{c}{ Concentration $(\boldsymbol{\mu g} / \mathbf{m l})$} \\
\cline { 2 - 7 } & MBC & MIC & MBC & MIC & MBC & MIC \\
\hline Staphylococcus aureus & 1.00 & 0.062 & 1.00 & 0.062 & 0.031 & 0.015 \\
Salmonella typhi & 0.5 & 0.25 & 0.062 & 0.015 & 0.125 & 0.007 \\
Proteus vulgaris & 0.25 & 0.062 & 0.25 & 0.031 & 0.031 & 0.015 \\
Bacillus subtilis & 0.062 & 0.031 & 0.5 & 0.125 & 0.062 & 0.007 \\
\hline
\end{tabular}

Escherichia coli and $13 \mathrm{~mm}$ against $S$. aureus at $0.04 \mathrm{~g} / 10 \mathrm{ml}$ and ethyl acetate extract with zone of inhibition $23 \mathrm{~mm}$ against E. coli and $13 \mathrm{~mm}$ against $S$. aureus at $0.03 \mathrm{~g} / 10 \mathrm{ml}^{[35]}$

Whereas in the present study, in ethyl acetate extract of C. cupreum, the most susceptible organism was to found be $P$. vulgaris, whereas $S$. aureus was the least sensitive at $0.5 \mathrm{mg} / \mathrm{ml}$ [Figure 6a]. Furthermore, in n-butanol extract of $C$. cupreum, the most susceptible organism was $B$. subtilis followed by $P$. vulgaris at $0.5 \mathrm{mg} / \mathrm{ml}$ [Figure 6a]. The antibacterial effect of tetracycline standard was also studied, and it was found that the most susceptible organism was $P$. vulgaris with zone of inhibition diameter $24.00 \pm 0.70 \mathrm{~mm}$ in diameter, followed by B. subtilis $23.50 \pm 0.70 \mathrm{~mm}$, S. typhi $18.00 \pm 0.87 \mathrm{~mm}$, and $S$. aureus $16.00 \pm 0.90 \mathrm{~mm}$ at $25 \mu \mathrm{g} / \mathrm{ml}$. In the present study, ethyl acetate and n-butanol extracts of $C$. cupreum showed moderate antibacterial activity. Whereas, chloroform and methanol extracts have not exhibited any antibacterial activity.

\section{Minimum bactericidal concentrations}

The MBCs of n-butanol and ethyl acetate extract of C. cupreum are shown in Table 3. The MBC values of n-butanol extract of C. cupreum exhibited by each organism is $0.062 \mathrm{mg} / \mathrm{ml}$ against $B$. subtilis $0.25 \mathrm{mg} / \mathrm{ml}$ against $P$. vulgaris $0.5 \mathrm{mg} / \mathrm{ml}$ against $S$. typhi and $1 \mathrm{mg} / \mathrm{ml}$ against $S$. aureus. Whereas, the ethyl acetate extract shows the MBC value of 0.062 against S. typhi, $0.25 \mathrm{mg} / \mathrm{ml}$ P. vulgaris, $0.5 \mathrm{mg} / \mathrm{ml}$ against $B$. subtilis, and $1 \mathrm{mg} / \mathrm{ml}$ against $S$. aureus respectively. The MBC values of standard compound observed for each organism are $0.007 \mu \mathrm{g} / \mathrm{ml}$ for B. subtilis and S. typhi and $0.015 \mu \mathrm{g} / \mathrm{ml}$ for $P$. vulgaris and $S$. aureus [Table 3].

\section{Discussion}

The C. cupreum was isolated from soil sample and identified on the basis of morphological, cultural, and molecular characteristics. The C. cupreum produces red-colored, extracellular, and water-soluble pigments on PDA and PDB. In biomass estimation, maximum dry yield was found in methanol extract followed by ethyl acetate extract, whereas in chloroform, less dry yield was found. In the present study, chloroform and methanol extracts of $C$. cupreum did not show antibacterial activity, which indicates that the extracts do not contain active compounds which could be responsible for antimicrobial activities. Whereas, ethyl acetate and butanol extracts showed antibacterial activity indicating the presence of broad-spectrum antibacterial substances in the C. cupreum which can be effectively applied against human pathogenic bacteria. These results show that these pigment extracts are exhibiting higher antimicrobial activities as compared to methonalic extracts from mushroom samples, which have exhibited MIC value in the range of $2.5-10 \mathrm{mg} / \mathrm{ml},{ }^{[35]}$ and they are also exhibiting better antimicrobial activity as even compared to the dichloromethane and ethyl acetate extract of the C. atrobrunneum against $E$. coli and $S$. aureus. ${ }^{\left[{ }^{[6]}\right]}$ The MIC and $\mathrm{MBC}$ values of our extracts are comparable with the values that are reported by certain endophytic fungal extracts. ${ }^{[37]}$ Further work is needed toward the evaluation of their antimicrobial potential against a wider range of microorganisms and finally the identification and characterization of the active compounds responsible for this activity that will provide new starting material for the development of novel antibiotics.

\section{ConcLusion}

The C. cupreum, a well-known soil fungus, was used to study the antibacterial activities by using its different solvents extracts. The C. cupreum was isolated from litter soil and grown in PDB. The obtained solvent extracts were subjected for testing antimicrobial activity. The butanol and ethyl acetate crude extracts showed significant antibacterial activities, and the results are comparable to standard antibiotic compound, respectively. The obtained results clearly confirmed that both the n-butanol and ethyl acetate extracts of the $C$. cupreum contain potential bioactive compounds that can be used in pharmaceutical purposes after toxicological and preclinical evaluations.

\section{Acknowledgment}

The authors are grateful to Head, Department of Microbiology and Biotechnology, Bangalore University, Bengaluru, Karnataka, India, for the use of laboratory facilities.

\section{Financial support and sponsorship}

Nil. 


\section{Conflicts of interest}

There are no conflicts of interest.

\section{ReFERENCES}

1. Finlay BB, Falkow S. Common themes in microbial pathogenicity. Microbiol Rev 1989;53:210-30.

2. Hacker J, Goebel W. Mechanism and methods for analysing phatogenicity. Swiss Biotechnol 1987;5:21-31.

3. Geng W, Yang Y, Wu D, Huang G, Wang C, Deng L, et al. Molecular characteristics of community-acquired, methicillin-resistant Staphylococcus aureus isolated from Chinese children. FEMS Immunol Med Microbiol 2010;58:356-62.

4. Iwase T, Uehara Y, Shinji H, Tajima A, Seo H, Takada K, et al. Staphylococcus epidermidis Esp inhibits Staphylococcus aureus biofilm formation and nasal colonization. Nature 2010;465:346-9.

5. Enright MC, Robinson DA, Randle G, Feil EJ, Grundmann H, Spratt BG. The evolutionary history of methicillin-resistant Staphylococcus aureus (MRSA). Proc Natl Acad Sci U S A 2002;99:7687-92.

6. Cimolai N. Methicillin-resistant Staphylococcus aureus in Canada: A historical perspective and lessons learned. Can J Microbiol 2010;56:89-120.

7. O’Mahony R, Abbott Y, Leonard FC, Markey BK, Quinn PJ, Pollock PJ, et al. Methicillin-resistant Staphylococcus aureus (MRSA) isolated from animals and veterinary personnel in Ireland. Vet Microbiol 2005; 109:285-96

8. Saris P, Taira S, Airaksinen U, Palva A, Sarvas M, Palva I, et al. Production and secretion of pertussis toxin subunits in Bacillus subtilis. FEMS Microbiol Lett 1990;56:143-8.

9. Weinstein L, Colburn CG. Bacillus subtilis meningitis and bacteremia; report of a case and review of the literature on subtilis infections in man. AMA Arch Intern Med 1950;86:585-94.

10. Bäumler AJ, Tsolis RM, Ficht TA, Adams LG. Evolution of host adaptation in Salmonella enterica. Infect Immun 1998;66:4579-87.

11. Crump JA, Luby SP, Mintz ED. The global burden of typhoid fever. Bull World Health Organ 2004;82:346-53.

12. Hornick RB. Pathogenesis of typhoid fever. J Egypt Public Health Assoc 1970;45:247-59.

13. Fields PI, Swanson RV, Haidaris CG, Heffron F. Mutants of Salmonella Typhimurium that cannot survive within the macrophage are avirulent. Proc Natl Acad Sci U S A 1986;83:5189-93.

14. Brenner DJ, Farmer J $3^{\text {rd }}$, Fanning GR, Steigerwalt AG, Klykken P, Wathert HG, et al. Deoxyribonucleic acid relatedness of Proteus and Providencia species. Int J Syst Bacteriol 1978;28:269-82.

15. Rubin RH, Tolkoff-Rubin NE, Cotran RS. Urinary tract infection, pyelonephritis and reflux nephropathy. In: Brenner BM, Rector FC, editors. The Kidney. Philadelphia, PA: The Saunders WB, Co.; 1986. p. $1085-143$.

16. Cherry WB, Lentz PL, Barnes LA. Implication of Proteus mirabilis in an outbreak of gastroenteritis. Am J Public Health Nations Health 1946;36:484-8.

17. Palanichamy V, Mitra B, Reddy N, Katiyar M, Rajkumari RB, Ramalingam $\mathrm{B}$, et al. Utilizing food waste by vermicomposting, extracting vermiwash, castings and increasing relative growth of plants. Int J Chem Anal Sci 2011;2:1241-6.

18. Duran M, Ponezi AN, Faljoni-Alario A, Teixerira MF, Justo GJ,
Duran N. Potential application of violacein: A microbial pigment. Med Chem Res 2012;21:1524-32.

19. Strudikova M. Microbial production of azaphilone metabolites. Chem Listy 2000;94:105-110.

20. Osmanova N. Azaphilones: a class of fungal metabolites with diverse biological activities. Phytochemist reviews 2010;9:315-342.

21. Kim JY, Lee YS, Choi HS. Molecular and morphological identification of fungal species isolated from rice Meju. Food Sci Biotechnol 2013;22:721-8.

22. White TJ, Bruns T, Lee S, Taylor J. Amplifi cation and direct sequencing of fungal ribosomal RNA genes for phylogenetics. In: PCR Protocols: A Guide to Methods and Applications. Academic Press San Diego; 1990 p. $315-22$.

23. Altschul SF, Madden TL, Schäffer AA, Zhang J, Zhang Z, Miller W, et al. Gapped BLAST and PSI-BLAST: A new generation of protein database search programs. Nucleic Acids Res 1997;25:3389-402.

24. Kang B, Zhang X, Wu Z, Qi H, Wang Z. Effect of $\mathrm{pH}$ and nonionic surfactant on component profile of intracellular and extracellular Monascus pigments. Process Biochem 2013;48:759-67.

25. Kim SW, Hwang HJ, Xu CP, Na YS, Song SK, Yun JW, et al. Influence of nutritional conditions on the mycelial growth and exopolysaccharide production in Paecilomyces sinclairii. Lett Appl Microbiol 2002;34:389-93

26. Premalatha B, Pradeep FS, Pradeep BV, Palaniswamy M. Production and characterization of naphthoquinone pigment from Fusarium moniliforme MTCC6985. World J Pharm Res 2012;1:1126-42.

27. Lathadevi KC, Chandi CR, Bapuji M, Gulnihal O. Pigment production from a mangrove Penicillium. Afr J Biotechnol 2014;13:2668-74.

28. Olsson L, Nielsen J. Online and in situ monitoring of biomass in submerged cultivations. Trends Biotechnol 1997;15:517-22.

29. Harborne JB. Phytochemical Methods: A Guide to Modern Techniques of Plant Analysis. London: Chapman and Hall; 1998.

30. Sofowora A. Medicinal plants and Traditional medicine in Africa Ibadan, Nigeria: Spectrum Books Ltd. 1993

31. Zhishen J, Mengcheng T, Jianming W. The determination of flavonoid contents in mulberry and their scavenging effects on superoxide radicals. Food Chem 1999;64:555-9.

32. Ebrahimabadi AH, Ebrahimabadi EH, Djafari BZ, Joukar KF, Mazouchi A, Batouli H. Composition and antioxidant and antimicrobial activity of the essential oil and extracts of Stachys inflata Benth from Iran. Food Chem 2010;119:452-8.

33. National Committee for Clinical Laboratory Standards. Reference Method for Broth Dilution Antifungal Susceptibility Testing of Yeasts. Approved Standard. Document M-27A. Wayne, Pennsylvania: National Committee for Clinical Laboratory Standards; 1997.

34. Nagda V, Gajbhiye A, Kumar D. Isolation and characterization of endophytic fungi from Calotropis procera for their antioxidant activity. Asian J Pharm Clin Res 2017;10:254-8.

35. Srimathi S, Devi NK, Muthumary J. Studies on antimicrobial activities of Chaetomium atrobrunneum Ames against selected microorganisms. J Exp Sci 2011;2:13-8

36. Daniela NN, Natalija AP, Haris A, Dafina V, Emilija I, Mitko K, et al. Screening of antibacterial and antifungal activities of selected macedonian wild mushrooms. Nat. Sci, Matica Srpska Novi Sad 2013; $124 ; 333-340$.

37. Pannapa P, Bajaree J, Acharawan T, Pattra S. Evaluation of endophytic fungi extract for their antimicrobial activity from Sesbania grandiflora (L.) Pers. Int J Pharm Biomed Res 2012;3:132-6. 